Tér és Társadalom 21. évf. 2007/2. 141-142. p.

Tér és Társadalom

XXI. évf. 2007 2: 141-149

\title{
KÖNYVJELZÖ
}

\section{BENKÖ PÉTER: MAGYARORSZÁG REGIONÁLIS POLITIKAI FÖLDRAJZA}

\author{
(Deák Bt., Budapest, 2006, 205 o.) \\ ERDŐSI FERENC
}

A több mint kétszáz oldalas könyv első rövid fejezete a téma indoklásával, a kutatási előzményekkel, a külföldi vonatkozások felvillantásával, koncepcionális és módszertani kérdésekkel foglalkozik.

A szerző deklarált szándéka, hogy meghaladja a szinte kizárólag szociológiai/politikai nézőpontú választási földrajzot, illetve az ilyen igénnyel készült jó néhány hazai munkát azzal, hogy földrajzi, valamint történelmi végzettségét is hasznosítva több tényezőre alapozottan, komplex szemlélettel vizsgálja a politikai régiókat. A politikai földrajzi kutatások Bernek Ágnes által lanszirozott nyolc tényezójével - a témához illeszthetőségüknek megfelelően - a szerző különböző mélységben foglalkozott. Így pl. Benkö számára a territoriális állam kérdéskörének csupán egyetlen aspektusa igazán releváns, nevezetesen, hogy a hazánk területét egykor hódító nagyhatalmak milyen hatást gyakoroltak az „alulról” képződő politikai régióink kialakulására. A szerző ugyan nem tekintette kutatómunka tárgyának a kormányzási struktúrát, azonban a régiók fejlödése szempontjából elemezte a kormányzati és önkormányzati tevékenység eredményeit. Ezzel szemben a politikai kultúra földrajzának bemutatása a mü egyik központi kérdése. Nagy hangsúlyt kapott az elemzések során a gazdaságföldrajz faktor, és kiterjedt a munka a „techno-politikai földrajz" problematikájára is, - amit a növekvő kockázatok mai világa igencsak indokol.

Végső fokon a terjedelmes tanulmány témáját és probléma megközelítési módját tekintve a Magyarországon eddig szokványoshoz képest nem csupán több aspektussal „bỏvített választási földrajz”, hanem regionális politikai földrajzi mủ.

A szerző a terjedelem 90\%-át a Lengyel László által elnevezett politikai (nagy) régiók, azaz Felső-Pannónia, Alsó-Pannónia és Hunnia politikai földrajz részletes leírásának és a legfontosabb részkövetkeztetések levonásának szentelte. E fejezetek minden esetben, következetesen az egyes politikai régiók társadalomtörténetének az őskortól a máig ívelő rövid összefoglalásával, valamint a mai helyzetük társadalmi/gazdasági jellemzésével kezdődnek. Ezt követi az időben és térben változó választási eredmények egyéni választókerületek, megyék és régiók szerint részletezett területi jellemzőinek a bemutatása (egészen az egymást váltó, vagy hosszabb ideig 
tevékenykedő képviselök megnevezéséig) és mindezekből a területi egységek politikai karakterére tett következtetések megfogalmazása.

Benkő Péter önmaga által választott meglehetősen hálátlan feladatra vállalkozott, amikor a politikai régiók politikai arculatát, irányultságát igyekezett objektív térségi adottságokkal összefüggésbe hozni. Minél több szabad választást hagyunk magunk után, annál kevesebb az olyan terület, amelynek a politikai karaktere viszonylag stabil. Időtálló. Igazán szoros kötődése a lakosság igen nagy részének nincs az egyes pártokhoz, hanem a kampánypropaganda hatásfokának és igen sok szubjektív körülménynek az éppen a választás napján érvényesülő hatására jelöli meg a párt nevét a fülkében - a tömegpszichózis és számos esetleges szubjektív tényezö által is befolyásoltan. Következésképpen a regionális politikai földrajz számára a jövőbeni történések folyamatos figyelemmel kísérése újabb muníciót ad és egyben lehetőséget is a korábbi helyzettel, illetve megállapításokkal való szembesítéshez. A legközelebbi tanulmány végére elkelne a kutatási eredményeket összegző néhány oldalas összefoglaló és probléma felvető befejező fejezet azok számára, akik a részletek iránt nem, de az eszenciális mondanivaló iránt annál inkább érdeklödnek. 